\title{
Literárněteoretická a literárněkritická propedeutika rusínsky nebo rusínská literárněteoretická a literárněkritická propedeutika?
}

\author{
Ivo Pospíšil
}

Andrej Antoňák: Úvod do teórie literatúry a literárnej kritiky / Вступ до теориії літературы. Высокошкольскый учебник. Пряшів/Prešov: Пряшівска универзіта в Пряшові, Инштітут русиньского языка и културы, 2015. 182 s. ISBN 978-80-555-1291-4.

Nová Evropa, jak se někdy říká novému uspořádání tohoto kontinentu po roce 1989 a později, v době, jež vynikla dělením, štěpením, zahraničním vměšováním, integrací, spojováním dobrovolným i násilným a válkami a jejich následky a cizími intervencemi (likvidace NDR a sjednocení Německa, rozpuštění Varšavské smlouvy a RVHP, likvidace SSSR, Československa a Jugoslávie, války s genocidními rysy na Balkáně, „humanitární bombardování“ Srbska, rozšiřování Evropské unie a NATO), oživila také nepotlačitelný projekt rusínského národa a jazyka, rusínské literatury a kultury. Nedávno jsme psali o jedné mezinárodní publikaci a jejím - konečně - českém vydání, které nutno uvítat, i když se nevyhnulo problémům. ${ }^{1}$

Tam jsme mimo jiné napsali, že př́liš nechápeme, proč byl text přeložen do češtiny z ukrajinštiny, když přece existuje rusínština, dokonce ve více verzích. Karpatští Rusíni žijí na severních a jižních svazích Karpat, kde asi do počátku 20. století tvořili většinu obyvatelstva na teritoriu zvaném někdy Podkarpatská Rus (18 000 čtverečních kilometrů od řeky Poprad po horní tok Tisy, na území Polska, Slovenska, Ukrajiny a Rumunska). Tři čtvrtiny karpatských Rusínů žije na Ukrajině (Zakarpatská oblast), na Slovensku v Prešovské Rusi, část jsou Lemkové v jihovýchodním Polsku, jako přistěhovalci

1 POSPÍŠIL, Ivo: Pohl'ady spoza Moravy. Rusini: národ odnikud? (Pavel Robert Magocsi: Národ odnikud. Ilustrované dějiny karpatských Rusinů. Texty k ilustracím Valerij Pad’ak. Z ukrajinského originálu s přihlédnutím k slovenské verzi přeložil Miloslav Kopecký. Užhorod: Vydavatelství V. Padala, 2014.) Slovenské pohlady, 2015, č. 7-8, s. $308-312$. ve Vojvodině (Bačka) a v Sriemu v bývalé Jugoslávii a dnešním východním Chorvatsku, v Praze a na severní Moravě (po 2. světové válce), v USA (v letech 1880-1919 se tam vystěhovalo 225000 karpatských Rusínů - obývají většinou severovýchod a sever), Kanadě, Argentině, Austrálii. Problémem je už jazyk, jenž by měl vlastně být základním identifikačním znakem Rusínů, když už nemají vlastní stát. Ale i tu je situace složitá a vedou se tam mezi lingvisty spory, stejně jako kolem slov Rusín a Rusnák. I laik po spatření různých rusínských textů z různých dob pochopí, že základní směřování jde k sbližování s ukrajinštinou a vzdalování ruštině, i když - jak známo - na Ukrajině nejsou Rusíni jako národ uznáváni. Problém Rusínů, kteří mají naše sympatie už proto, že každý člověk nebo skupina lidí by měla mít možnost volit si národní identitu svobodně, je neexistence vlastního státu a neustálé zpochybňování jejich národní identity, vynucované nebo pragmaticky zdůvodňované přijímání jiné identity - ukrajinské, polské, slovenské apod. z důvodů přežití, nemluvě o násilných transferech, tzv. výměnách obyvatelstva a transportech, které rusínské etnikum decimovaly, rozptýlily a vzdálily od jeho původní vlasti. Upř́ímně řečeno nevím, jaký bude další rusínský osud, ale přál bych mu, aby byl lepší než ten dosavadní. Zde ovšem záleží na samotných Rusínech, zda chtějí udržet svou identitu a rozvíjet především svůj jazyk a kulturu. Od toho se ostatně odvíjelo i národní obrození v 19. století - doba je však těmto snahám nakloněna nyní mnohem méně. ${ }^{2}$

2 Srov. ibidem, s. 308. 
O to cenněǰš́ je publikace, která je vlastně vysokoškolskou učebnicí, úvodem do teorie literatury a literární kritiky, jež vznikla v novém Ústavu rusínského jazyka a literatury na Prešovské univerzitě. Jde v této chvíli zejména o jazyk jako takový, ale také o jazyk vědy, literární vědy, tedy i metajazyk zvláště. Andrej Antoňák, prešovský Rusín, rusista a ukrajinista, se zde pustil na pole, které je pro Rusíny důležité a vyvedl j na denní světlo literárněteoretickou a literárněkritickou propedeutiku na křídovém papíre ve dvou částech a jedenácti kapitolách. Je to text dobrý, podává základní poznatky často odvozované z jiných autorových věcí a samožrejmě ze sekundární literatury, který obepíná všechny důležité okruhy tradiční poetiky a teorie literatury a speciálně literární kritiky. Je to určitý metodologický a aplikační kompromis mezi tradiční ruskou a sovětskou a tzv. západní literární vědou, jež se výrazněji prosazuje jen v některých oddílech (teorie textu, diskurs).

První část se skládá z úvodních partií a základních definic: co je to teorie literatury, krásná/umělecká literatura, literární věda, přičemž z blízkých disciplín zdůrazňuje kulturologii: uvědomme si, že právě on takto koncipoval některé své literárněhistorické a sociologicko-kulturologické práce. ${ }^{3}$ Druhá kapitola první části se týká umění obecně, tedy obecné uměnovědy a filozofie jako - podle Antoňáka - základ umění (s tím bych nesouhlasil) a světový názor (Weltanschauung, світогляд) a jeho vztah k umělecké tvorbě. Problematická je typologie světového názoru: sociálně historický a emocionální (existenciální) - takto obecně asi umění nelze klasifikovat ani ve vztahu k filozofii; vzniká tak schéma, jež

3 Viz jeho ranou publikaci Sociokultúrna interpretácia románov M. Šolochova (Tichý Don, Rozoraná celina). Prešov: ManaCon, 1998. Viz také naše recenze jeho dalších prací: POSPÍŠIL, Ivo: Texty ze sociokulturni interpretace (Andrej Antoňák: Sociokultúrna interpretácia umeleckého textu (na textoch ruskej literatúry a kultúry). Acta Facultatis Philosohicae Universitatis Prešoviensis, Monographia 52. Prešov: Filozofická fakulta Prešovskej univerzity, 2004. 111 s.). Opera Slavica, 2006, č. 1, s. 58-59; týž: Potřebná přiručka o ruském světě (Andrej Antoňák: Ruská literatúra 20. storočia I. Kompendium. Prešov: Filozofická fakulta Prešovskej univerzity v Prešove, 2007. Новая русистика, 2009, Но. 1, s. 92-93. studenty může svádět $\mathrm{k}$ neúměrné simplifikaci. „Povinnou“ součástí takové propedeutiky je vztah krásné (umělecké) literatury a estetiky, užitečná je kapitola o vkusu, sporná zase o pravdě v umění. Třetí kapitola je věnována tematice, obsahu a formě, syžetu, fabuli a konfliktu. Zde se chvíli zastavíme: autor se snaží - stejně jako kdysi Josef Hrabák, ale méně sofistikovaně, spojit několik konceptů v jeden. Stejně jako se Hrabák pokoušel své strukturalistické východisko začlenit do marxistického konceptu teorie odrazu, snaží se Antoňák tradiční hegelovské a marxistické, resp. sovětské aplikované kategorie obsahu a formy, tedy kategorií dialektiky, začlenit do formalistického konceptu fabuly a syžetu. Je dobře, že to tu je, tyto pojmy spolu samozřejmě souvisejí (obsah - forma - syžet - fabule), ale nezapadají do sebe jako proslulé matrjošky, jdou paralelně, juxtapozičně, někde se prolínají více, jinde méně. Podobně je to $s$ kategorií tzv. obrazu, což u východních Slovanů, tedy i u Rusínů, znamená všechno možné: trop, figuru, literární postavu: od toho odvozené sloveso „zobrazovat“, také někdy nadužívané i v české teorii. Zde nelze nevzpomenout na A. (O.) A. (O.) Potebňu a jeho teorii obrazu a slova. Sem autor také včlenil problém kompozice; čekal bych spíše celistvost, tedy holistické pojetí artefaktu. Čtvrtá kapitola - v paradigmatu „nižší“ - se týká jazyka krásné literatury. Chybí mi tu prostá charakteristika poetické/estetické funkce jazyka (R. Jakobson): tak by se vysvětlilo takřka vše podstatné včetně metafory, jež tu trochu trčí. Problém „řeči“ je tu také jaksi „navíc“ - vztah k jazyku je víceméně zatemněný. Pátá kapitola je stylologická, ale vztah k poetice a jazyku krásné literatury tu není podrobněji rozveden. Ani zde Antoňák neopomene uvést známý protiklad stylu a metody - ze sovětské estetiky, kde šlo zejména o tzv. socialistický realismus. Šestá kapitola je „(post)modernizační“: pojednává totiž o textu a diskurzu, ale spíše marginálně - je tu intencionalita, ale v podstatě nic tu není o intertextualitě. Sedmá kapitola se už týká evolučního aspektu uměleckého díla, problematiky uměleckého procesu, jak tomu rádi ř́kají východní Slované. Cenná je partie o periodizaci, kde autor využívá i ná- 
zorů „otce Rusínů“ A. Duchnoviče (1803-1865). Nezapomíná tu ani na ideál a jeho ztělesnění $\mathrm{v}$ artefaktu, $\mathrm{V}$ jedné podkapitole se také zminuuje o periodizaci rusínské literatury. S tím ovšem souvisí část o literárních směrech, školách a skupinách (tak to nazývá) - výkladová partie je bohužel hodně neúplná a chybí tu i proslulá Hrabákova definice literárních proudů a směrů podle subjektivity sebereflexe (viz jeho Poetiku, 1973). Osmá kapitola pokrývá literární žánry. V závorce autor uvádí pojem genologie a je škoda, že jde o formální uvedení, nikoli hloubkové. Samozřejmě genologie a žánry jsou dvě věci: uvádí se zde žánrová systematika, ale jen fragmentárně, tradičně aristotelovská, aniž autor naznačuje její problematičnost. Žánry jsou vztaženy k rusínské literatuře a na ni aplikovány. Devátá kapitola je versologická, zase mírně vztažená k rusínské poezii. Desátá kapitola věnovaná interpretaci je zase jen naznačena, ale to lze vysvětlit propedeutickým rázem textu a nutností prostorové sevřenosti.

Druhá část začíná pojednáním o literární kritice: zde by se měla dotknout hlavně pojmosloví, nebot celý problém literární vědy a teorie, stejně jako všech uměnověd, je terminologický: terminologii nelze vzhledem k historickým kořenům a „anatomii“ a „fyziologii“ jazyka radikálně měnit, lze ji pouze vysvětlovat, definovat a interpretovat jednotlivé pojmy a jejich význam v určitých kulturních okruzích a národních jazycích. Zde by se třeba slušelo vyložit specifikum rusínské terminologie - na rozdíl od ukrajinské a ruské či běloruské - jaký ten rozdíl je, pokud vůbec nějaký je, jestli tu probíhá delimitace - to je jen místy naznačováno. To přímo a úzce souvisí s otázkou v titulu recenze: jde jen o transpozici jiných východoslovanských teorií literatury, zejména ruské a ukrajinské, do rusínštiny, nebo o koncipování svébytné rusínské literárněteoretické a literárněkritické propedeutiky? Rád bych se přiklonil k druhé variantě. Součástí pojednání o literární kritice (angl. criticism, franc. critique mají mnohem širší význam než něm. $L i$ teraturkritik) je i výklad literárněkritických žánrů a stručné přehled vývoje literární kritiky - sice neúplný, ale pro dané potřeby dostačující. Užitečný je malý slovníček pojmů a samozřejmě soupis literatury: těžko ho posuzovat, je hodně subjektivní a nikoli up to date.

Zkrátka a dobře: kniha dobře koncipovaná, přehledná, rozhodně vhodná i pro širší okruh čtenářů než pro Rusíny a rusínské vysokoškoláky. Jaký význam má v rozvoji rusínské teorie literatury, její didaktiky a literárněvědné terminologie a metodologie nejsem schopen posoudit, ale vzhledem k tomu, co se dnes nabízí jako propedeutická suma, je to knížka standardní. Přitom není beztvará a beztvářná, ale zračí se v ní v rozumné míře i individuální přístup autora: spíše než v oblasti metodologické však v akcentaci určitých problémových okruhů (kulturologie, ideologie, filozofie) a v aplikační sféře rusínské. Co mi tu chybí: silnější zření ke skutečně nejnovější sekundární literatuře, kritičtější zhodnocení toho, co už bylo vymyšleno, někteří by tu asi nejvíce postrádali naratologii, hrdinu dnešního literárněvědného diskurzu. A samožrejmě kompaktní výklad společenských funkcí uměleckého/literárního díla. Slabší je tu propojenost jednotlivých částí, jejich okruhů a termínů, tedy deficit holistického pojetí artefaktu. A ještě více je tu již zmíněná juxtapozičnost, paralelita místo kauzálního propojení. Nejsem stoupencem silné kauzality a chápu, že tato otázka, byt tak klíčová, je složitá a různě interpretovatelná, ale určitá balance je tu asi nezbytná. Sám však mnohem více postrádám komparatistiku a genologii (ta je tu aspoň zmíněna). Zde se pak nabízí srovnání rusínsko-ukrajinsko-rusko-běloruské, tedy v rámci východoslovanského komplexu, ale také např. rusínsko-slovensko-české, když už kdysi Rusíni žili - sice jen 20 let - i na území Československa, jež bylo i jejich státem. Možná by neškodila i silnějš́i inovace metodologická a snad i ještě individuálnější prrístup. Doufám, že autor bude v této práci na poli rusínské literární vědy pokračovat a že k tomu využije i svých zkušeností slovenského a ukrajinského literárního historika, kritika a hlavně rusisty. Již za tuto svou propedeutiku zaslouží uznání. 